Regional and Business Studies (2020) Vol 12 No 2, 65-76

Szent István University Kaposvár Campus, Faculty of Economic Science, Kaposvár doi: $10.33568 /$ rbs. 2520

\title{
The Effects of Wine Regions on the Profitability of the Hungarian Winers
}

\author{
Boglárka SzERB, András Bence SzERB \\ Szent István University Kaposvár Campus, H-7400 Kaposvár, Guba Sándor u. 40.
}

\begin{abstract}
The aim of our research is to analyse the profitability and efficiency performance of different Hungarian wine regions. In our study, we make the initial assumption that wine regions function as a separate agglomeration zone, an industry cluster in the life of wineries. Consequently, it makes sense to evaluate profitability and efficiency not at the corporate level but at the wine region level. In the study, we used the DuPont scorecard system, which is now preferred by companies for planning and control purposes. According to the results of the 2017 large wine test, we divided the Hungarian wine regions into four groups, and in the case of wineries that cannot be classified as wine regions, we created two more groups. Our results are consistent with the theory of agglomeration zones and industrial clusters. In winemaking, it can also be demonstrated that wine regions, which can be considered as a special industrial cluster, have a significant impact on the economic performance of wineries.
\end{abstract}

Keywords: wine sector, wine region, dupont analysis, profit margin, asset productivity JEL codes: M21, R12, Q14

\section{INTRODUCTION}

The global wine market has undergone significant changes in recent decades. In addition to traditional or so called "old world" wine producing countries, the "new world" wine producing countries are playing an increasing role. "Old world" countries include countries with traditional and long-standing wine cultures and documented wine histories, including some countries in the European Union (e.g., France, Italy, Spain, Hungary) and the Middle East (e.g., Turkey). "New world" wine producers include areas occupied by European conquerors following great geographical discoveries, where viticulture was established later (e.g., United States, Chile, Argentina, New Zealand, Australia) (Balogh, 2016).

In recent decades, the world's vineyards have been declining. Around the turn of the millennium the territory was 7.8 million hectares, while in 2018 the global production area was nearly four percent lower, about 7.4 million hectares, according to the $O I V$ (2019). In particular, the area of "old world" wine-producing countries has declined significantly, mainly due to the European Union's wine market reform in 2008, which was intended to restore the reputation of community wines and balance 
supply and demand. In parallel, several Asian countries have significantly increased their territories in the "new world" due to government incentives (Jiao \& Ouyang, 2019). In recent decades, the U.S. has moderately increased its area, while China has nearly tripled its wine producing territory $(O I V, 2019)$.

There have also been recent changes in wine consumption. Global consumption rose by nearly ten percent by the turn of the millennium. This increase, in addition to the stagnation of "old world" wine consumption, was due to the increase in "new world" wine consumption. Since 2011, the U.S. has been the largest consumer of wine $(O I V, 2019)$. Global wine trade, and thus indirectly even wine consumption, according to a study by Balogh (2016) and Balogh and Jámbor (2018), has a negative effect on geographical distance, while a positive effect has a number of cultural factors such as former colonial relationship, common religion, or common language.

Hungary is one of the traditional wine-producing countries of the "old world". It has a long history of viticulture, so it is one of the defining elements of Hungarian culture and economy (Törökné Kiss, 2014; Balogh, 2015), thanks to which Hungarian literature is also rich in economic research related to the sector.

Similarly to the trends of "old world" wine-producing countries, Hungary was also characterized by a decrease in wine-producing areas after the turn of the millennium, as shown in Figure 1. In 2000, 113 million hectares of vineyards were cultivated in Hungary, which by 2013 fell to just under 62 million hectares, and by 2018, according to OIV data, it had risen again to 69 million hectares, which still represents a decrease of almost $40 \%$ compared to the millennium. According to Szamosköziné (2018) a favourable grubbing-up and restructuring promotions, an aging grape and wine-producing society, a changing legal background, administrative burdens, asymmetric information shifts, increasingly extreme weather, aging plantations, specialist shortages, economic crisis cause a lack of cooperation and mistrust, as well as unfavourable profitability leads to declining producing areas.

Figure 1

\section{Hungary's grape growing area between 2000 and 2018 (thousand hectares)}

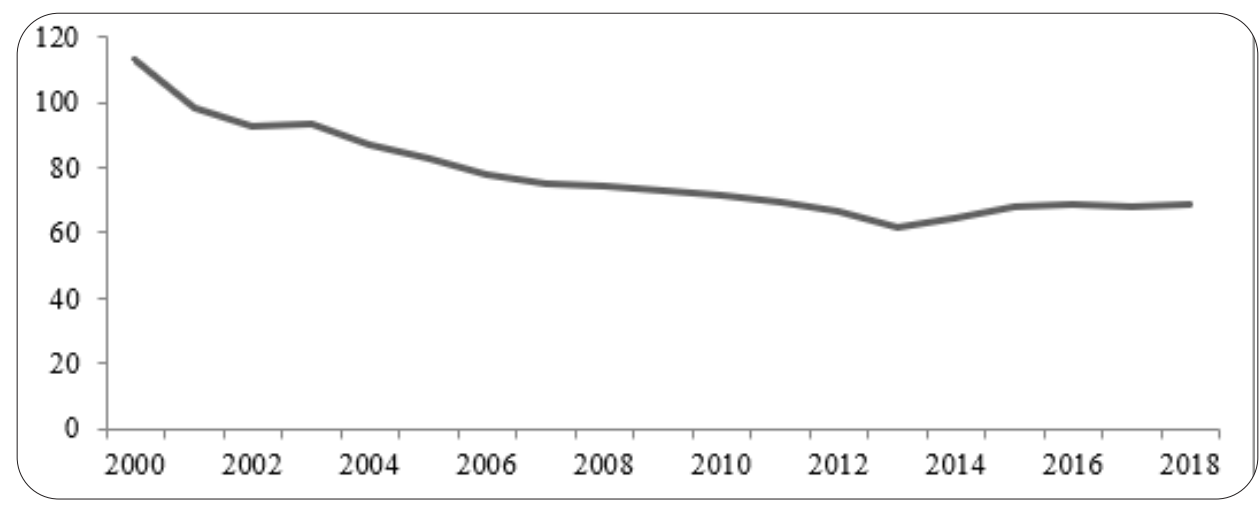

Source: OIV, 2019 
Wine grapes are produced on about $85-90 \%$ of Hungary's grape producing areas, most of which are white grape varieties today, which is $69 \%$ of the planted area. The proportion of this varies between wine regions, but the national average has been between $65-70 \%$ in recent years. The situation was similar in 2019 as well, the area planted with blue grapes was 19694 hectares, while with white grapes it was 44693 hectares (HNT, 2019).

Based on the data of KSH (2020) (Figure 2), Hungary's wine production shows declining values after the turn of the millennium, similarly to other "old world" wine-producing countries. In 2000, Hungary produced more than 430 million litres of wine, and until the accession to the European Union, our production exceeded 500 million litres in two years. Subsequently, there was a significant decline in the market in 2005 and domestic wine production reached a low point in 2010 with a production value of about 180 million litres. In the last few years, domestic wine production has been rising again.

\section{Figure 2}

\section{Hungarian wine production between 2000 and 2018 (million litters)}

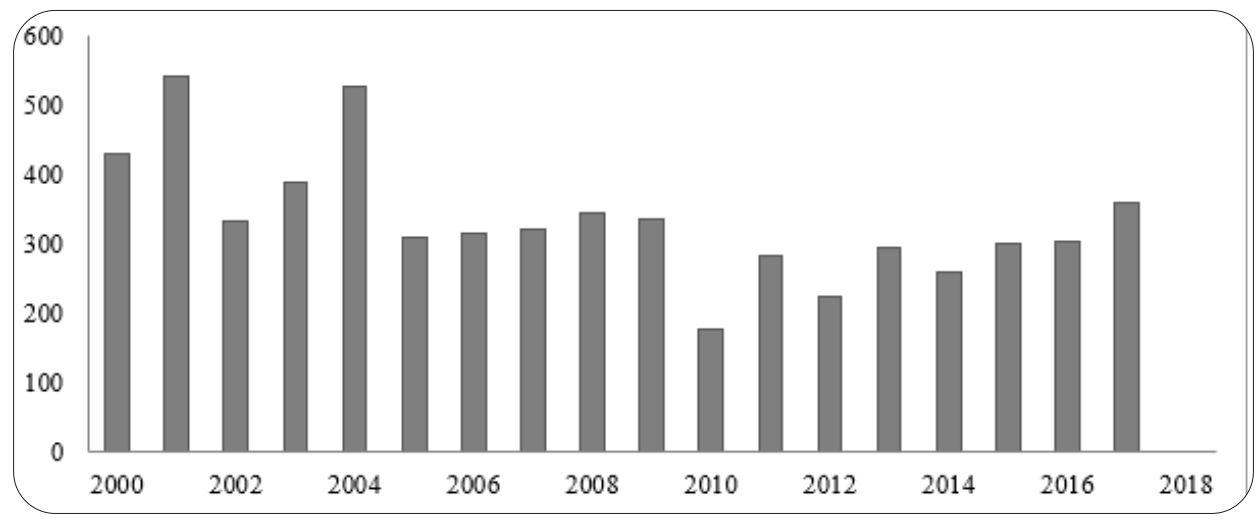

Source: Based on KSH 2020

There are six wine areas in Hungary (Felsö-Pannon, Felső-Magyarország, Tokaj, Danube, Pannon, Balaton) and within them a total of twenty-two wine regions (Figure 3 ), which are responsible for domestic wine production and are also essential parts of Hungarian wine tourism. They are unique in terms of their climate, topography, soil and history, so the wines produced in the area are also different from each other.

The concept of a wine area is defined in the law CCXIX of 2012. The law states: „a voluntary association of wine regions established for the promotion of their common interests and for the protection of the origin, quality and origin of the products they produce, consisting of a number of wine regions with similar wine-growing traditions, geographically close or adjacent". In order to interpret the definition, it is important to know the concept of the wine region, which was established in the 
law XVIII. of 2004: „a set of production areas with similar climatic, topographical, pedological conditions, plantations with a characteristic variety composition and cultivation, specific viticultural and wine-growing traditions and from which specific wine and wine-related products are derived."

\section{Figure 3}

\section{Wine map of Hungary}

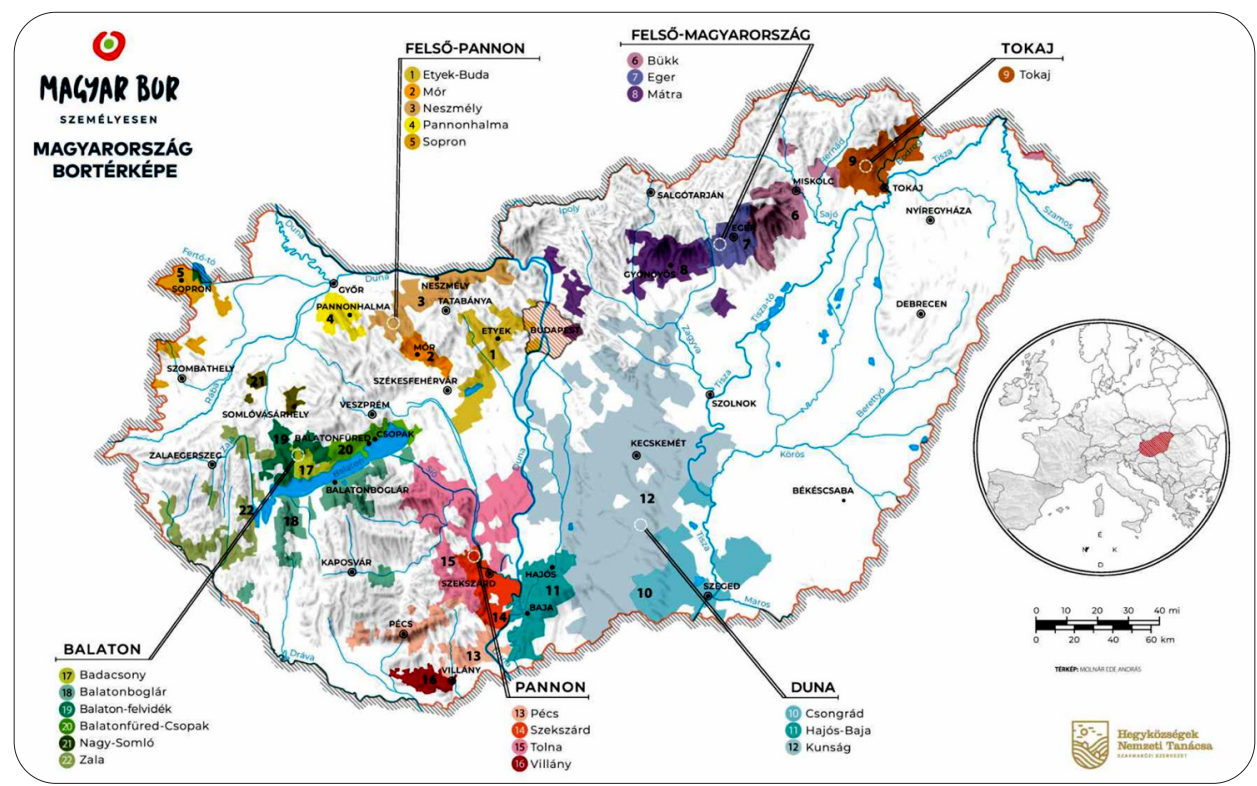

Source: Magyar Bor n.d.

It is also clear from the definition that wine areas and wine regions, which are separated on the basis of historical, cultural and natural (geographical and climatic) conditions, have become one of the most important differentiating factors of the domestic wine product market. The results of several studies (Totth \& Szolnoki, 2019; Harsányi \& Hlédik, 2017; Darvasné Ördög et al., 2014; Harsányi, 2012; GFK, 2008) prove that the origin of the wine plays a prominent role in the purchasing decisions of Hungarian consumers. In this respect, it is understandable that in recent years several domestic researches have been done concerning the different marketing issues of a wine region (Bartos-Slezák \& Vas-Guld, 2018; Kiss, 2014; Kispál, 2014a; Gálné Czékus, 2013; Molnár et al., 2009), or the economic analysis of the wineries (Kismarjai, 2015; Kispál, 2014b).

However, we are not aware of any work that has comprehensively analysed the impact of wine regions on the profitability of wineries. We want to fill this gap with our study. The aim of our research is to analyse the profitability and efficiency performance of different Hungarian wine regions. 
In the next chapter of the article, we show the positive impact of a territorial agglomeration or industrial area, including wine regions, on the enterprises located within its area. Then we describe the data and methods used in the research. Finally, we publish our results and the conclusions that can be drawn from them.

\section{THEORETICAL BACKGROUND - ECONOMICS OF AGGLOMERATION EFFECTS}

In our study, we make the initial assumption that wine regions function as a separate agglomeration zone, an industry cluster in the life of wineries. As a result, it makes sense to evaluate profitability and efficiency not at the corporate level but at the wine region level. However, before presenting the primary research, we would like to present briefly the theory of agglomeration zones and industry clusters.

By industrial cluster we mean a group of companies belonging to a given industry, competing and cooperating at the same time, suppliers and service providers are capable of meeting the needs of the industry, and related industries and institutions are concentrated in a well-defined geographical area (Porter, 2000). The geographical proximity between the enterprises and institutions that make up the cluster, as well as the high territorial concentration of the industry, offer a number of advantages (Csonka and Fertö, 2017, 2020; Csonka et al., 2018) for the actors of the cluster, which is called positive agglomeration externality, positive agglomeration effect or agglomeration advantage (Lengyel et al., 2012). Agglomeration advantages can be divided into static and dynamic agglomeration advantages according to Lengyel and Leydesdorff (2008) and Capello (2002). By static agglomeration benefits we mean primarily "classic" external effects that reduce costs. Static advantages include, for example, a locally available specialized workforce, a specialized supplier base, a scientific environment and the presence of large, diversified input and/or output markets. The dynamic benefits, on the other hand, stem from an overflow of information and knowledge. In globalized competition, dynamic agglomeration effects, especially spillover effects, are increasingly able to provide a real lasting competitive advantage. According to industry relationships, we can distinguish between horizontal (within industry) and vertical (between industries) spillovers (Wolfe and Gertler, 2004; Bathelt, 2005). The available empirical research findings on the impact of vertical and horizontal spillover on firm performance (productivity) are inconsistent (Wang and Wu, 2016). Several studies confirm the negative effect of horizontal spillover and the positive effect of vertical spillover (Jeon et al., 2013; Le and Pomfret, 2011; Liu et al., 2009; Jordaan, 2008). However, there are researches that show opposite results as well (Barbosa and Eiriz, 2009; László and Balázs, 2007). It can also be seen from the above that corporate agglomerations also carry negative externalities. There is empirical evidence that in a given area and at a given time, these negative externalities may have a stronger impact than the positive ones, namely high territorial concentration in the sector may ultimately reduce corporate performance (Marco-Lajara et al., 2016). 


\section{MATERIAL AND METHOD}

In the paper, we used the DuPont scorecard system, which is according to Katits et al. (2019), popular among companies for planning and controlling purposes, as their advantages include simplicity, transparency and comparability of companies operating in different sectors and of different sizes. In the model the top indictor is the ROA (return on assets), which we divide into profit margin and asset turnover branches (Kemény, 2009). In the study, we want to compare the economic performance of Hungarian wine regions and area-independent wineries. To achieve this goal, the economic data of companies / enterprises are taken from the Crefoport Scholar database.

According to the results of the Great Wine Test in 2017 (Nagy Bor Teszt, nd), the Hungarian wine regions were divided into four groups, and two more groups were created in the case of wineries that cannot be classified in any of the regions (Table 1 ). Wineries in group 5 typically operate in smaller areas which do not belong to any wine region, while the wineries in Group 6 are interested in several wine regions due to their integrated operation.

Table 1

Grouping of wineries

\begin{tabular}{|l|l|}
\hline \multicolumn{1}{|c|}{ Group } & \multicolumn{1}{c|}{ Wine region/ settlement/ winery } \\
\hline 1. Highly popular & Villány-Siklósi, Egri, Tokaj-hegyaljai \\
\hline 2. Preferred & Badacsony, Balaton-felvidéki, Szekszárdi \\
\hline 3. Less preferred & $\begin{array}{l}\text { Balatonfüred-Csopaki, Etyek-Budai, } \\
\text { Soproni, Balatonboglári, Mátraaljai }\end{array}$ \\
\hline 4. Least preferred & $\begin{array}{l}\text { Csongrádi, Hajós-Bajai, Kunsági, Ászár- } \\
\text { Neszmélyi, Móri, Pannonhalma-Sokoróaljai, } \\
\text { Nagy-Somlói, Pécsi, Bükkaljai, Tolnai }\end{array}$ \\
\hline $\begin{array}{l}\text { 5. Wineries not belonging to a wine } \\
\text { region }\end{array}$ & $\begin{array}{l}\text { ex.: Székesfehérvár, Debrecen, Pomáz, Érd, } \\
\text { Nagytarcsa Dunakeszi }\end{array}$ \\
\hline 6. Area-independent wineries & $\begin{array}{l}\text { ex.: Varga Pincészet Kft., Szent Imre } \\
\text { Pincészet Kft., WEINHAUS Kft., } \\
\text { VINOTRADE Kft. }\end{array}$ \\
\hline
\end{tabular}

\section{RESULTS}

The results of the DuPont model are summarized in Table 2. The three wine regions of Group 1 (Villány-Siklósi, Egri, Tokaj-hegyaljai) have the most operating enterprises compared to all the six categories. In the examined years (2009-2018) the number of winery enterprises increased from 160 to 176 , while in one enterprise there were on average 6-8 employees, which means a high employment rate compared to the other groups. This group includes such famous wineries as Csányi Pincészet, Ostoros bor, 
Bock Pincészet, Varsányi Pincészet and Royal Tokaj Pincészet, among others. Compared to the fact that the wineries are known and based on the results of the Great Wine Test, nearly $50 \%$ of consumers prefer these wineries, the results of the DuPont index are the weakest compared to the wineries of all the six categories. The worst years were 2012 and 2016, when the loss exceeded HUF 15 million on average. Group 1 achieved the most convincing result in 2018 , when the ROA peak was $-0.24 \%$, which is due to the improvement in the profit margin $(-0.84 \%)$, which is due to the relatively high sales revenue (HUF 102 million) and the relatively low profit loss (HUF 858 thousand). It is true that wineries in this group are successful and internationally recognized, but their deteriorating competitive position is mainly caused by innovative wineries in emerging wine regions and their high costs result in a loss-making marketing year.

Table 1

\section{Grouping of wineries (\%)}

\begin{tabular}{|c|c|c|c|c|c|c|c|c|c|c|c|c|}
\hline Group & Indicator & 2009 & 2010 & 2011 & 2012 & 2013 & 2014 & 2015 & 2016 & 2017 & 2018 & Average \\
\hline \multirow{3}{*}{1.} & Profit margin & $-1,58$ & $-2,10$ & $-2,10$ & $-15,31$ & $-1,47$ & $-14,29$ & $-7,43$ & $-21,10$ & $-4,25$ & $-0,84$ & $-1,99$ \\
\hline & Asset tu & 32,46 & 34,22 & 33,53 & 34,53 & 35,08 & 27,71 & 24,81 & 26,68 & 28,03 & 27,97 & 30,44 \\
\hline & ROA & $-0,51$ & $-0,72$ & $-0,71$ & $-5,29$ & $-0,52$ & $-3,96$ & $-1,84$ & $-5,63$ & $-1,19$ & $-0,24$ & $-1,99$ \\
\hline \multirow{3}{*}{2.} & Profit & 18,09 & 15,15 & 22,33 & 14,78 & 15,74 & 16,95 & 14,63 & 13,76 & 11,09 & 9,83 & 14,63 \\
\hline & Asset tu & 32,15 & 32,70 & 31,91 & 24,82 & 25,37 & 23,01 & 29,97 & 28,67 & 26,72 & 25,25 & 27,33 \\
\hline & ROA & 5,82 & 4,95 & 7,13 & 3,67 & 3,99 & 3,90 & 4,39 & 3,95 & 2,96 & 2,48 & 4,00 \\
\hline \multirow{3}{*}{3.} & Profit margin & 9,56 & $-1,09$ & 2,59 & 4,31 & 3,48 & 2,41 & 3,83 & 4,78 & 9,23 & 7,95 & 4,85 \\
\hline & Asset turnover & 37,67 & 31,67 & 21,86 & 27,87 & 30,59 & 29,11 & 30,49 & 32,11 & 31,20 & 32,21 & 30,42 \\
\hline & ROA & 3,60 & $-0,35$ & 0,57 & 1,20 & 1,07 & 0,70 & 1,17 & 1,53 & 2,88 & 2,56 & 1,48 \\
\hline \multirow{3}{*}{4.} & Profit margin & $-5,54$ & 0,27 & $-0,04$ & 8,59 & 5,21 & 5,49 & 2,83 & 3,84 & 11,81 & 13,61 & 4,60 \\
\hline & Asset turnover & 40,09 & 50,57 & 50,50 & 46,44 & 46,05 & 45,78 & 49,61 & 46,61 & 48,93 & 49,78 & 47,37 \\
\hline & ROA & $-2,22$ & 0,13 & $-0,02$ & 3,99 & 2,40 & 2,51 & 1,40 & 1,79 & 5,78 & 6,77 & 2,18 \\
\hline \multirow{3}{*}{5.} & Profit margin & $-45,01$ & $-8,40$ & $-59,33$ & 8,45 & 14,66 & 0,55 & $-12,02$ & 22,12 & $-11,24$ & 10,94 & 0,91 \\
\hline & Asset turnover & 8,35 & 7,65 & 5,34 & 13,62 & 11,77 & 12,75 & 17,20 & 18,19 & 16,49 & 18,87 & 13,81 \\
\hline & ROA & $-3,76$ & $-0,64$ & $-3,17$ & 1,15 & 1,72 & 0,07 & $-2,07$ & 4,02 & $-1,85$ & 2,06 & 0,13 \\
\hline \multirow{3}{*}{6.} & Profit margin & 4,14 & 4,19 & 1,83 & 2,69 & 5,79 & 4,65 & 5,17 & 3,58 & 6,55 & 10,02 & 5,07 \\
\hline & Asset turnover & 75,97 & 81,03 & 83,15 & 93,83 & 68,89 & 75,73 & 72,73 & 74,69 & 72,89 & 72,65 & 76,17 \\
\hline & ROA & 3,15 & 3,40 & 1,52 & 2,52 & 3,99 & 3,52 & 3,76 & 2,67 & 4,77 & 7,28 & 3,87 \\
\hline
\end{tabular}

The group of preferred wine regions (Group 2), similarly to the first group, includes the wineries of three wine regions (Badacsonyi, Balaton-felvidéki, Szekszárd). The number of enterprises is the lowest compared to the other groups, in the examined years (2009-2018) it ranged from 51 to 60. The best-known wineries in this category include Bodri Pincészet, Laposa Birtok, Lajvér Pincészet and Takler Pincészet és Borászat, among others. The wineries of the second category have an outstanding economic performance compared to the other groups. The ROA ranged from $2.48 \%$ to $7.13 \% .2009$ and 2011 were outstandingly good years. Although sales show an increasing trend year on year, this asset is not reflected in proportional profit, due to the declining trend in profit margins, but even so, the wineries in the group are 
the most economically efficient. The emerging wineries belonging to this group have innovative ideas, are open for development, and thus have an increasingly strong competitive position. Their marketing strategy is not only for wine sales, but for their hospitality and appearance at various sport events (e.g. UltraBalaton, Bodri Trail, Wine Region Half Marathon).

The third category (Group 3) includes wineries from five wine regions (Balatonfüred-Csopaki, Etyek-Budai, Sopron, Balatonboglár, Mátraaljai). The group’s bestknown wine businesses include Nyakas Cellar, Twickel Vineyard, Légli and last but not least Bujdosó. While in 2009 the return on assets (ROA) was outstandingly positive at $3.6 \%$, in 2010 this figure was $-0.35 \%$. In both years, the profit margin and the profitability ratio caused the fluctuation, within lead to high profit after tax in 2009 and the loss of HUF 666 thousand in 2010.

The group of least favoured wine regions (Group 4) includes wine regions with lesser known or poorer quality wines (Csongrád, Hajós-Baja, Kunsági, Ászár-Neszmélyi, Móri, Pannonhalma-Sokoróalja, Nagy-Somló, Pécs, Bükkalja). Among the products of these wine regions, we have traditionally found non-quality table wines, but in recent years, thanks to the development of technology and demanding winemakers, good quality, light wines are also made. In cased of Group 4 the results of the DuPont analyses showed a loss in 2009 and 2010. As in the other groups, the profitability indicator of the companies caused the loss, which was caused by the profit after tax of the enterprises in a given year. In 2017 and 2018, due to the high profit, the profit margin was outstanding (12\% and 14\%), thus the top indicator (ROA) of the system was also high $(6 \%$ and $7 \%)$. The asset efficiency showed exceptionally high results $(40-50 \%)$ in the ten years of the examined period.

Group 6 includes wineries that purchase products from several wine regions, ie.they are not linked to an area or a single wine region, so we call them area-independent wineries. Relatively few wineries belong to the group, but the higher the number of employees they have. This includes large companies such as Varga Pincészet. The wineries in the sixth group are large and efficient wineries. Their sales and profits were also the highest in the years under review, compared to the other groups. The efficiency rate was outstandingly high in all the years, with values between $73 \%$ and $94 \%$. From the results of the sixth group, we can conclude that the wineries belonging to the group operate economies of scale due to their large plant size. Another reason for the high efficiency indicator is the integration, because these companies buy grapes from several wine regions, they have partners in several wine regions, thus they are less influenced by the weather conditions of a given area.

One of the best and most successful companies in the group is Varga Pincészet, which also has cellars in the Badacsony, Eger and Tokaj wine regions. They produce grapes on nearly 250 hectares and also purchase from third party producers. Thanks to their continuous technological developments, they have become one of the most developed and successful wineries in Hungary. 


\section{CONCLUSIONS}

In our study, we classified Hungarian wineries into six groups, based on the result of the Great Wine Test in 2017. The first group includes wineries from different wine regions which are considered as highly popular according to the costumers. These wineries have a long history and usually make their wines using their traditional process. Their brand is well-known on the market and their products are popular among consumers. On the other hand, our results show that the companies belonging to this group were loss-making during all the examined ten years. Behind this is the deterioration of the competitive position, which may be caused by the expansion of other wine regions. In addition to optimizing production, providing additional services to the consumers may change this trend. Besides this, the use of new marketing tools can help them to reach new consumers on the market (eg.: support various cultural or sport events).

The second group included wineries in wine regions that have become increasingly prominent in recent years and their products are in a preferred category by the consumers. The results of the DuPont scorecard also prove that these businesses are performing well, with the best results on the profitability side. No wonder, as innovative and youthful wineries such as Lajvér and Laposa belong here, which, with their modern look, can also appeal to the younger, gastronomic-demanding circle of consumers. The wineries belonging to this group become more and more popular among wine lovers, their continuous developments and their appearance at different cultural and sport events will strengthen their market position.

We consider it important to highlight the group of area-independent wineries. The best and best-known example of these wineries is the Varga Pincészet, which also has sites in three wine regions (Badacsony, Tokaj-Hegyalja, Eger). Thanks to this integrated operation and the large volume of grapes purchased, the specifics of each vintage in a wine region have less impact on the company's production. In addition, thanks to their large operational size and managerial skills, they can operate optimally and size efficiently. The other companies in this category also had outstanding efficiency indicators, which can be attributed to similar characteristics to Varga Pincészet.

Our results are consistent with the theory of agglomeration zones and industrial clusters. In winemaking, it can also be demonstrated that wine regions, which can be considered as a special industrial cluster, have a significant impact on the economic performance of wineries.

\section{ACKNOWLEDGMENT}

This study was conducted in the framework of the research EFOP 3.6.2-16-201700018 „Produce with the nature - Agroforestry as a New outbreaking possibility”. 


\section{REFERENCES}

Balogh, J. M. (2015). Investigating the effect of geographical distances and cultural proximity on the Hungarian wine trade. Society and Economy, 37(4), 513-529. https://doi.org/10.1556/204.2015.37.4.6

Balogh, J. M. (2016). A földrajzi távolság, a kulturális hasonlóság és a szabadkereskedelem hatása a borkereskedelemre. Közgazdasági Szemle, 63(7-8), 858-881. https://doi.org/10.18414/KSZ.2016.7-8.858

Balogh, J. M., \& Jámbor, A. (2018). The role of culture, language and trade agreements in global wine trade. AGRIS on-line Papers in Economics and Informatics, 10. 17-29 https://doi.org/10.22004/ag.econ.281642

Barbosa, N., \& Eiriz, V. (2009). Linking corporate productivity to foreign direct investment: An empirical assessment. International Business Review, 18(1), 1-13

Bathelt, H. (2005). Geographies of production: Growth regimes in spatial perspective (II) - Knowledge creation and growth in clusters. Progress in Human Geography, 29(2), 204-216.

Capello, R. (2002). Entrepreneurship and spatial externalities: Theory and measurement. The Annals of Regional Science, 36. 387-402.

Csonka, A., Bareith, T., Gál, V.A., \& Fertő, I. (2018). Spatial Pattern of CAP Measures Promoting Agroforestry in Hungary. AgBioForum 21(2), 127-134.

Csonka, A., \& Fertő, I. (2017). Válság- és agglomerációs hatások a magyarországi sertéstartásban. Közgazdasági Szemle 64(2), 105-122. https://doi.org/10.18414/ KSZ.2017.2.105

Csonka, A., \& Fertő, I. (2020). Structural change and agglomeration in the Hungarian pork industry. European Planning Studies. 28(9), 1756-1770. https://doi. org/10.1080/09654313.2019.1687652

Darvasné Ördög E. (szerk.), Székelyhidi K., Felkai B. O., Szabó D. (2014). Az európai uniós és nemzeti élelmiszer-minőségrendszerek és védjegyek helyzete Magyarországon. AKI, Budapest

Gálné Czékus, I. (2013). Fogyasztói Vélemények Az Egri Borvidék És Az Egri Bikavér Vonatkozásában. Acta Carolus Robertus, 3. 49-58.

GFK Hungária Piackutató Intézet (2008). Bor feltáró kutatás, a Nemzeti Bormarketing Program keretében. GFK, Budapest

Harsányi D. (2012). Az internetezők borfogyasztási szokásai I. Bor és piac, 12 (11-12), $24-25$.

Harsányi D., \& Hlédik E. (2017). A hazai borfogyasztói szegmensek 2016-ban. In Bányai E. \& Lányi B., Töröcsik M. (eds.) Tükröződés, társtudományok, trendek, fogyasztás. Egyesület a Marketing Oktatásért és kutatásért (EMOK) XXIII. országos konferencia, Tanulmánykötet. Pécs, 179-188.

HNT (Hegyközségek Nemzeti Tanács) (2019). Termőterület és termésmennyiség, http://www.hnt.hu/statisztikak/termoterulet-es-termesmennyiseg/ 
Jeon, Y., Park, B. I., \& Ghauri, P. N. (2013). Foreign direct investment spillover effects in China: Are they different across industries with differenttechnological levels? China Economic Review, 26. 105-117.

Jiao, L., \& Ouyang, S. (2019). The Chinese Wine Industry. In: Ugaglia, A. A., Cardebat, J.-M., \& Corsi, M. (eds.). The Palgrave Handbook of Wine Industry Economics. Springer International Publishing, 225-246.

Jordaan, J. A. (2008). Intra- and inter-industry externalities from foreign direct investment in the Mexican manufacturing sector: New evidence from MexicanRegions. World Development, 36(12), 2838-2854

Katits, E., Szalka, É., Nagy, F., \& Könczöl, T. (2019). A magyar top cégek a turizmusban, avagy egy sikerre éhes ágazat pénzügyi diagnózisa. Multidiszciplináris kihívások, sokszínủ válaszok, 2, 71-97.

Kemény, G. (2009). Mutatószámrendszerek a vállalatvezetésben. RAABE Tanácsadó és Kiadó Kft., Budapest.

Kismarjai, B. (2015). Borászati vállalkozások a Móri Borvidéken. Földrajzi Közlemények 139(1), 54-65.

Kispál, G. (2014a). „Ízlések és borok”-a csongrádi borok pozícionálása. Gazdálkodás, $58(6), 1-11$.

Kispál, G. (2014b). A csongrádi borklaszter megvalósíthatósága és fenntarthatósága. In Forum on Economics and Business 17(119-120) 98.

Kiss, K. T. (2014). Marketing analysis of the Villány wine region. Acta Agraria Debreceniensis, 55, 119-123.

KSH (2020). Bormérleg. (https://www.ksh.hu/docs/hun/xstadat/xstadat_hosszu/ elm11.html

László, H., \& Balázs, M. (2007). Does distance matter in spillover. Economics of Transition, 15(4), 781-805.

Le, H. Q., \& Pomfret, R. (2011). Technology spillovers from foreign direct investment in Vietnam: Horizontal or vertical spillovers? Journal of the Asia Pacific Economy, 16(2), 183-201.

Lengyel, B., \& Leydesdorff, L. (2008). A magyar gazdaság tudásalapú szerveződésének mérése. Közgazdasági Szemle, 6. 522-547.

Lengyel, I., Fenyővári, Zs., \& Nagy, B. (2012). A közelség szerepének újraértelmezése az innovatív üzleti kapcsolatokban. Vezetéstudomány 43(3) 19-29.

Liu, X., Wang, C., \& Wei, Y. (2009). Do local manufacturing firms benefit from transactional linkages with multinational enterprises in China? Journal of International Business Studies, 40(7), 1113-1130.

Magyar Bor (n.d.). Borrégiók. https://bor.hu/borregiok

Marco-Lajara, B., Claver-Cortés, E., Úbeda-Garcia, M., \& Zaragoza-Sáez. P. (2016). A dynamic analysis of the agglomeration and performance relationship. Journal of Business Research 69, 1874-1879.

Molnár, E., Májer, J., Lakatos, A., Poór, J., \& Brazsil, D. (2009). A Balatoni Borvidéki Régió hosszú távú marketing stratégiája. Pannon Egyetem Agrártudo- 
mányi Centrum-Szőlészeti és Borászati Kutatóintézet, Badacsony, http://www. szbki-badacsony. hu/files/files/bbr_strategia. pdf

Nagy Bor Teszt (nd). 2017-es gyorseredmények. http://nagyborteszt.hu/eredmenyek OIV (2019). 2019 Statistical Report on World Vitiviniculture. http://oiv.int/en/ technical-standards-and-documents/statistical-analysis

Porter, M.E. (2000). Location, competition, and economic development: local clusters in a global economy. Economic development quarterly, 14(1), 15-34.

Slezák-Bartos Zs., \& Vas-Guld Zs. (2018). Egy borvidék-egy település marketing szempontú vizsgálata. I. Nemzetközi Turizmusmarketing Konferencia - Generációk a Turizmusban. Tanulmánykötet. Pécsi Tudományegyetem, Közgazdaságtudományi Kar, Pécs.

Szamosköziné Kispál, G. (2018). A magyarországi bor termékpálya jövedelmezőségének vizsgálata. Doktori értekezés, Gazdálkodás- és Szervezéstudományok Doktori Iskola, Szent István Egyetem, Gödöllő.

Totth, G., \& Szolnoki, G. (2019). A magyarországi borfogyasztói szokások és a borpiac elemzése. Gazdálkodás, 63(1), 22-39. https://doi.org/10.22004/ag.econ.284793

Törökné Kiss K. Á. (2014). A villányi borvidék marketingelemzése, Agrártudományi Közlemények 55, 119-124.

Wang, C.C., \& Wu, A. (2016). Geographical FDI knowledge spillover and innovation of indigenous firms in China. International Business Review 25, 895-906.

Wolfe, D. A., \& Gertler, M. S. (2004). Clusters from the inside and out: Local dynamics and global linkages. Urban Studies, 41(5-6), 1071-1093.

Corresponding author:

\section{Boglárka SzERB}

Szent István University, Kaposvár Campus,

Doctoral School in Management and Organizational Sciences

H-7400 Kaposvár, Guba S. 40.

email: boglarka.szerb@gmail.com

(C) Copyright 2020 by the authors.

This is an open access article under the terms and conditions of the

Creative Commons attribution (CC-BY-NC-ND) license 4.0.

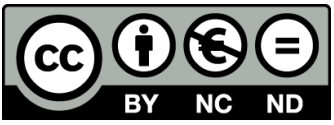

